else that is useful to anyone concerned with making maps. It is stiff with wrinkles such as " Ink will not readily collect on the straight edge if a finger is first slightly moistened with oil and then wiped along the bevelled edge ..."

W. B. H.

The Elements of Field Geology. By G. W. Himus and G. S. Sweeting. University Tutorial Press, 1951, pp. viii +268 . Price $14 s$.

There is a good deal in this small book that will be very useful to the Elementary student of geology and help him to make a good start in the subject along sound lines. This applies particularly to Part I of the book wherein the general considerations of field work leading up to the principles involved in mapping are regrettably given precedence over the study of specimens collected in the field (Part II).

Lapworth used to say that there were only two necessities requisite for the young geologist : a good pair of eyes and a good geological hammer. For geology is essentially an out-of-door science and the details of mapping work which may follow the realization of the relation of topography to outcrop will only be successful as a logical consequence of rock formations: the student should also endeavour to "see solid" (in 3 dimensions) but this will probably come gradually and may be more difficult of attainment.

There is surely far more in elementary field work than just geological map-making though these are certainly an important part of it, but what about the question, for example, of the origin of springs and principles involving wells relating to water supply? Recognition of differences in mode of occurrence as between Igneous and Sedimentary rocks, and general account of features controlling Mining and all its modern possibilities all are primarily field topics.

The matter dealt with in Part II is far too much stressed : it should be only a corollary to field work already carried out. There are also many books already which deal with this part of the subject.

The section dealing with identification of fossils, by what was (mistakenly) believed an original method. actually used in America in 1909, is below the standard of the rest of the book. The subject matter purports to be dealt with frem the Palaeozoological and botanical standpoint, but it is unfortunately not always accurate and there is little to suggest the importance of fossils as stratigraphical indices or even a general plan of the evolution of any group. An elementary section on this part of the subject now seems to be badly needed in a modern textbook. It is far more needed than more details for identification of different forms of which many books already have been published.

G. L. E.

\title{
CORRESPONDENCE
}

\section{PLEISTOCENE SECTIONS AT BARRINGTON}

SIR,--The recent paper by Mr. B. W. Sparks (Geol. Mag., lxxxix, p. 163) on the Quaternary deposits of Barrington puts on record some extremely interesting points regarding both the stratigraphy and palaeontology of the beds, and all interested in this field will welcome the accession of a young and energetic worker to the difficult problems involved.

The conclusions given in his Barrington paper may perhaps lead people to accept them as beyond question although he has been careful to qualify many of his statements. While not denying that his arguments have much weight I feel it may be as well to point out that his interpretation leaves us with a number of unsolved problems. For instance, it may be easy to explain the absence of Boulder Clay on the slopes of the hills but much more difficult 
to explain why no trace of it has been found in the wide valley, if as he claims the valley at its present depth is pre-boulder clay.

The stratigraphical position of the Hippopotamus bed at Barrington has always been in doubt and the dating of this important deposit must, 1 think, wait for stronger evidence than that adduced by Mr. Sparks which rests upon the correlation of the upper part at the Hippopotamus site with the lower part of the Cement works site and the argument that the valley was its present depth in pre-boulder clay times.

The age of the plateal boulder clays is still a matter upon which much work remains to be done before finality is reached and I feel it would be dangerous to accept this evidence as being more than a possible indication of the relative age of the drift of the plateau and the fossiliferous deposits of the valley bottoms.

SedGWIK M MUSEUM,

W. B. R. KiNG.

CAMBRIDGE.

$25 t h J_{l l l}, 1952$.

Sir, - In his letter, Professor King has raised two of the main problems of the Pleistocene history of the Cam valley on which the Barrington sections have some bearing, namely the relation between the boulder clay and the topography, and the stratigraphical position of the Hippopotamus bed.

In my paper I have stated that the Barrington sections indicate that the main Ashwell branch of the Cam valley predates the boulder clay. Such a conclusion is in accordance with the evidence from some of the other valleys, e.g. those of the Bourn Brook and the Saffron Walden branch of the Cam, where boulder clay can be seen in the bottoms of the valleys, and in accordance with the dissection of the plateau west of Cambridge to 100 feet O.D. beneath the boulder clay. By analogy, and without the additional evidence of the Barrington sections, onc would expect the Ashwell branch, the largest valley in the district, to predate the boulder clay. Yet there is the puzzling absence of boulder clay from the valley. If the valley is post-boulder clay, it is difficult to see why such an enormous valley has been eroded here, while little erosion was taking place elsewhere. If it is pre-boulder clay, one must assume that subglacial streams or melt-water streams in the retreat stage resorted the boulder clay into sands and gravels as soon as it was deposited. Such a suggestion seems to me at least as plausible as the supposition that a continental ice-sheet must have deposited a continuous sheet of boulder clay within 40 miles of its margin.

The other problem is that of the position of the Hippopotamus bed. The main point in my argument is not the correlation of the lower bed at the Cement Works with the upper bed at Cardo's pit. Both these deposits contain Helicella geveri, a rare snail not found elsewhere in the Cam valley. In addition, Succinea oblonga, previously recorded from Cardo's pit, is indistinguishable from Succinea arenaria from the Cement Works, while the other Succinea oblonga recorded from the Cam valley appear, as far as one can tell from these degenerate shells, to be true oblonga. The presence of these two rare shells in both deposits makes their correlation fairly certain, especially as the lithology is the same as well. The crux of the argument is the lithology of the chalk solifluxion: if, by some freak, it could have occurred with boulder clay capping the ridge, my argument fails. But I do not think this likely, as elsewhere in the Cam valley one can see solifluxions derived from high ground capped by boulder clay and their lithology is entirely different from that of the lower bed of Eastwoood's Cement Works.

The position of the Hippopotamus bed also seems unique by virtue of its fauna. There are to my mind significant differences between the snail fauna of the Hippopotamus bed and that of the Histon Road beds, which have shells practically identical with those found at Barnwell Abbey, Trumpington, and Granchester, and which postdate the boulder clay and belong to the last interglacial period. 
Finally, I would like to stress, as Professor King does in his last paragraph, that the description of the Barrington sections was intended to give a relative dating of local deposits, as links between the plateau boulder clay and the valley gravels are uncommon.

\section{DePARTMENT OF GEOGRAPHY, CAMBRIDGE.}

16th August, 1952.

B. W. Sparks.

\section{MALVERN TECTONICS}

SiR, - l have read Dr. Blyth's recent contribution to Malvern tectonics (Geol. Mag., lxxxix, 1952, p. 185) with great interest. From my own experience of mapping in the south Malverns, one or two points arise, which may be worth adding to Dr. Blyth's account.

I am in agreement with Dr. Blyth's interpretation of the Malverns as a segment of the PreCambrian basement brought up along lines of fracturing: also with his conclusion that the Malvern mass has been forced westward over the adjacent Palaeozoic rocks, rather than the latter driven beneath the PreCambrian by eastward reflected Hercynian movements. In either case, however, the most remarkable feature in this area is surely the moderate nature of the folding in Palaeozoic sediments immediately west of the thrust mass. Here Silurian beds show an open and fairly summetrical folding, modified by slight overturning against the Hereford Beacon. Not only the narrowness of the affected belt of sediments, but the degree of disturbance also, supports Dr. Blyth's contention that the Malvern block is better related to localized movement in the basement, than to crustal shortening on a regional scale. Traced westward this open folding of the Palaeozoic strata passes into a north-south belt of more intense folding and faulting, lying just east of Ledbury. This was demonstrated in the Ledbury tunnel section, and is clearly expressed at the surface from Hope End to Clenchers Mill Wood, south of Eastnor-a distance of four miles. Thus there is the anomaly of gentle folding immediately adjacent to the Malvern thrust mass, with a parallel zone of more intense deformation further away. The latter may perhaps be the superficial expression of a second and equally localized disturbance in the concealed PreCambrian basement.

A second more obvious point is briefly mentioned by Dr. Blyth, but would seem to warrant greater stress. The principal and latest group of movements contributing to the present Malvern range is probably of Carboniferous age ; but the Malverns have been a line of recurrent disturbance through very long periods of geological time. The nature and physical conditions of the PreCambrian rocks exposed in the Gullet and Hollybush quarries for example, confirm their lengthy and complex history. The occurrence of fragments apparently derived from these same rocks in the basal conglomerates of both Cambrian and Llandovery beds hereabouts, the presence of included slices of Silurian strata caught up within the thrust PreCambrian, and the occurrence of Warren House pillow lavas at Clutters cave, suggest a repeated elevation and submergence long before Carboniferous times. The present structural pattern of the Malverns represents the cumulative effects of a series of long-sustained disturbances, each early phase contributing in varying degree, but now largely masked by the overriding effects of Hercynian movement.

\section{Department of Geology, OXFORD.}

12th June, 1952. 